\title{
Membrane-bound Enterotoxin of Vibrio cholerae
}

\author{
By PRABHAVATHI B. FERNANDES AND MANFRED E. BAYER \\ The Institute for Cancer Research, The Fox Chase Cancer Center, Philadelphia, \\ Pennsylvania I9I I , U.S.A.
}

(Received 24 June 1977; revised 9 August 1977)

The mode of transport of the complex toxin molecule of Vibrio cholerae (which has a mol. wt of 84000 and consists of several subunits) across the inner and outer membranes of $V$. cholerae is not known. In this study we found two peptides in the outer and inner membranes of $V$. cholerae which may be the form in which the toxin subunits are transported across the membrane. We examined two growth conditions: aerobic growth at $37^{\circ} \mathrm{C}$, when most of the synthesized toxin is membrane-bound; and anaerobic growth at $37^{\circ} \mathrm{C}$, when little toxin remains membrane-bound, the toxin being released into the growth medium. When $V$. cholerae was grown aerobically at $37^{\circ} \mathrm{C}$, the outer and the inner membranes contained two peptides with mol. wts of approximately 22000 and 6000 which were not found in the outer or the inner membrane of anaerobically grown cells. Sodium deoxycholate, which releases membrane-bound toxin, released several peptides including the 22000 and the $6000 \mathrm{~mol}$. wt peptides. Trypsin also released the 22000 and $6000 \mathrm{~mol}$. wt peptides. Purified cholera toxin had three kinds of peptides, of mol. wt 2 I 000 ( $\mathrm{A}_{1}$ peptide), I I 000 (B subunit) and 5000 ( $A_{2}$ peptide). We postulate that the membrane peptides may be precursors of the A subunit of the toxin molecule.

\section{INTRODUCTION}

Vibrio cholerae enterotoxin is a complex molecule consisting of two fragments, A and B. The A fragment is made of two disulphide-linked polypeptides, subunit $A_{1}$ (2 I 000 mol. wt) and subunit $A_{2}(5000 \mathrm{~mol}$. wt), and the $B$ fragment $(56000 \mathrm{~mol}$. wt) consists of four to six identical polypeptides, the B subunits (I I000 mol. wt) (Finkelstein, 1975). Although the growth conditions for toxin production have been characterized, the nature of the subunits during the transport of the toxin across the inner and outer membrane of $V$. cholerae is not known. When $V$. cholerae is grown under optimal growth conditions (aerobic; $37^{\circ} \mathrm{C}$ ) most of the toxin remains membrane-bound (Fernandes \& Smith, 1977). The release of this membrane-bound toxin is augmented by growth under suboptimal growth conditions (anaerobic; $37^{\circ} \mathrm{C}$ ) during which the organism has a defective envelope structure (Fernandes, Clark \& Smith, 1977). We have examined the inner and the outer membranes of $V$. cholerae grown under aerobic and anaerobic conditions to determine the nature of the membranebound form of the toxin.

In Gram-negative bacteria the mechanism by which macromolecules are transported across the inner and the outer membranes is not known. We have used toxin production as a model to study the mechanism of secretion in Gram-negative bacteria. We have found two polypeptides, with similar molecular weights to the $A_{1}$ and $A_{2}$ subunits of the toxin, in the inner and outer membranes of $V$. cholerae grown aerobically at $37^{\circ} \mathrm{C}$ but not in membranes of bacteria grown anaerobically at $37^{\circ} \mathrm{C}$. As significant amounts of toxin remain membrane-bound only when bacteria are grown aerobically at $37{ }^{\circ} \mathrm{C}$, we believe that toxin release might be mediated by host factors such as an anaerobic intestinal environment containing bile salts. 


\section{METHODS}

Organism and incubation conditions. Vibrio cholerae strain 569B (obtained from Dr John C. Feeley, N.I.H., Bethesda, Maryland, U.S.A.) was grown in modified Syncase medium (Fernandes \& Smith, 1977). Cultures were incubated at $37^{\circ} \mathrm{C}$ aerobically or anaerobically in a BBL GasPak jar. The organisms were collected at mid-exponential phase $\left(9 \times 10^{8}\right.$ colony-forming units $\left.\mathrm{ml}^{-1}\right)$ and used for membrane preparations.

Preparation of inner and outer membrane proteins. The inner membrane proteins and the outer membrane vesicles were prepared using Triton X-100 as described by Schnaitman (197I). The solubilized inner membrane proteins were precipitated with 2 vols $95 \%(\mathrm{v} / \mathrm{v})$ ethanol for $30 \mathrm{~min}$ at $-20^{\circ} \mathrm{C}$ and the precipitate was resuspended in distilled water. The outer membrane vesicles were washed twice and resuspended in distilled water. The protein concentrations of the membrane preparations were determined by the method of Lowry et al. (195I) using bovine serum albumin as the standard. The protein concentration in the samples was adjusted to $2 \mathrm{mg} \mathrm{ml}^{-1}$ and the samples were stored at $-70^{\circ} \mathrm{C}$.

The purity of outer membrane preparations was examined by testing for the absence of NADH oxidase as described by Osborn et al. (1972). The degree of contamination of the outer membrane preparation by the inner membrane proteins was 5 to $10 \%$.

Solubilization of outer membrane proteins. Outer membrane proteins were solubilized from outer membrane vesicles using $2 \%(\mathrm{v} / \mathrm{v})$ Triton X-100 plus 10 mM-EDTA in Io mM-Hepes buffer as described by Schnaitman (I97I). The proteins were precipitated with 2 vols cold $95 \%$ ethanol for $30 \mathrm{~min}$. The precipitate was dissolved in $0.02 \mathrm{M}$-phosphate buffered saline (PBS) pH 7.2 to a final concentration of $2 \mathrm{mg}$ protein $\mathrm{ml}^{-1}$.

Double diffusion in agarose gels. Micro-Ouchterlony double diffusion agarose plates were prepared as described by Holmgren, Lönnroth \& Svennerholm (1973). The wells were filled with $5 \mu 1$ of each reactant which were allowed to diffuse for $\mathrm{I}$ to 4 days in a humid atmosphere at room temperature. The antisera used were (i) cholera antitoxin (obtained from Wellcome Research Laboratories) prepared by immunization of horses with purified cholera toxin (A and B subunits) and (ii) anticholeragenoid (obtained from Dr R. A. Finkelstein, University of Texas Southwestern Medical School, Dallas, Texas, U.S.A.) prepared by immunization of horses with choleragenoid. Choleragenoid is an antigen which cross-reacts with cholera toxin and is found in the growth medium of $V$. cholerae under certain conditions. It is non-toxic since it consists of only the B subunit.

Sodium dodecyl sulphate (SDS)-polyacrylamide gel electrophoresis. The slab gel electrophoresis apparatus was similar to that described by Ames (1974). The gels were prepared and run as described by Laemmli $\&$ Favre (1973) except that in the electrode buffer the concentration of Tris was decreased to $0.025 \mathrm{M}$ and that of glycine to $0.192 \mathrm{M}$. These modifications allowed better resolution of bands. The inner and outer membrane preparations (containing $2 \mathrm{mg}$ protein $\mathrm{ml}^{-1}$ ) were suspended in an equal volume of sample buffer containing $0.05 \mathrm{M}$-Tris $/ \mathrm{HCl} \mathrm{pH} \mathrm{6.8,5 \% (v/v)} \mathrm{mercaptoethanol,} 2 \%(\mathrm{w} / \mathrm{v})$ SDS and $10 \%(\mathrm{v} / \mathrm{v})$ glycerol. The mixtures were boiled for $5 \mathrm{~min}$ and applied to gels. Bovine serum albumin, catalase, ovalbumin (Worthington Biochemical Corporation), and tobacco mosaic virus protein (mol. wt 17500; obtained from Dr John C. McMichael, The Institute for Cancer Research, Philadelphia, U.S.A.) were used as molecular weight markers. Purified cholera enterotoxin was diluted in the sample buffer to $50 \mu \mathrm{g} \mathrm{ml}^{-1}$ and boiled for 5 min before application to gels. Gels were scanned using a densitometer and the relative amounts of the protein bands were determined from these scans as described by Lugtenberg et al. (1976). When peptides with molecular weights of less than 15000 had to be resolved, the acrylamide concentration in the gels was increased to $18 \%(\mathrm{w} / \mathrm{v})$.

Sodium deoxycholate extraction of toxin from whole cells. Organisms from $500 \mathrm{ml}$ of culture incubated aerobically at $37^{\circ} \mathrm{C}$ for $6 \mathrm{~h}$ were collected and resuspended in $0.1 \%(\mathrm{w} / \mathrm{v})$ sodium deoxycholate (Fischer Scientific Co., Philadelphia, U.S.A.) in Syncase medium. The suspension was incubated for $10 \mathrm{~min}$ at $37^{\circ} \mathrm{C}$ with gentle agitation and was then centrifuged at $8000 \mathrm{~g}$ for $\mathrm{I} 5 \mathrm{~min}$. The supernatant fluid was filtered through a $0.45 \mu \mathrm{m}$ pore-size filter (Millipore) and precipitated with $95 \%$ ethanol at $-20{ }^{\circ} \mathrm{C}$ for $30 \mathrm{~min}$. This precipitate was resuspended in distilled water and stored at $-70^{\circ} \mathrm{C}$. Outer and inner membrane proteins were prepared from the bacterial pellet.

Trypsin digestion of envelopes. Bacteria from $500 \mathrm{ml}$ of culture were incubated aerobically at $37^{\circ} \mathrm{C}$ for $6 \mathrm{~h}$ in Syncase medium and envelopes were prepared as described by Rosenbusch (1974). The envelopes were digested with $25 \mu \mathrm{g}$ trypsin $\mathrm{ml}^{-1}$ as described by Inouye \& Yee (1972). The trypsin digest was stored at $-70^{\circ} \mathrm{C}$. 


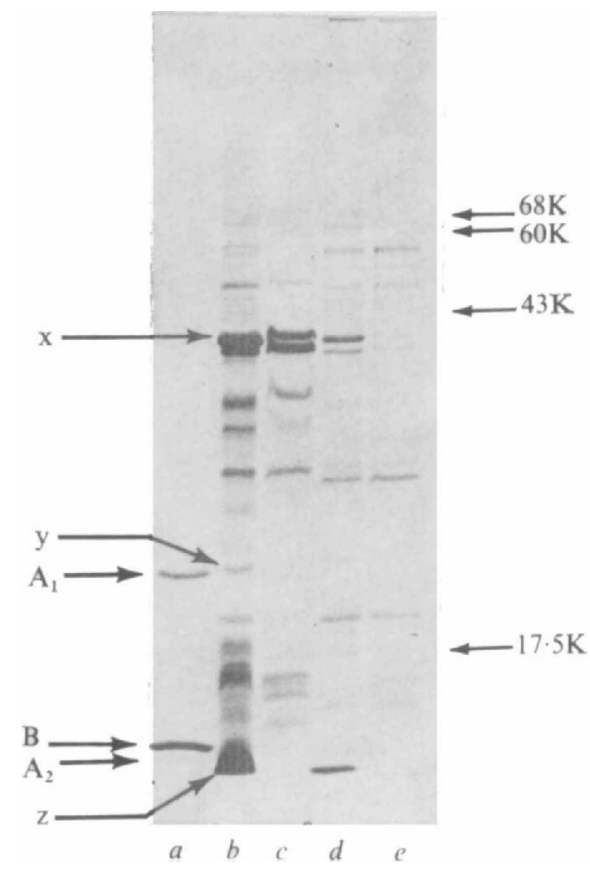

Fig. I. Envelope proteins of $V$. cholerae $569 \mathrm{~B}$ separated by SDS-polyacrylamide (10 \%) gel electrophoresis. (a) Purified cholera toxin; (b) outer membrane proteins, aerobic $37^{\circ} \mathrm{C}$; (c) outer membrane proteins, anaerobic $37^{\circ} \mathrm{C} ;(d)$ inner membrane proteins, aerobic $37^{\circ} \mathrm{C} ;(e)$ inner membrane proteins, anaerobic $37^{\circ} \mathrm{C}$. All samples contained $2 \mathrm{mg}$ protein $\mathrm{ml}^{-1}$. Standards are indicated by their mol. wt $\left(\times 10^{-3}\right)$ followed by $\mathrm{K}: 68 \mathrm{~K}$, bovine serum albumin; $60 \mathrm{~K}$, catalase; $43 \mathrm{~K}$, ovalbumin; I7.5K, tobacco mosaic virus protein. Arrows $A_{1}(2 I K), B(I I K)$ and $A_{2}(5 K)$ indicate toxin subunits. Arrows $x, y$ and $z$ indicate the $42 \mathrm{~K}, 22 \mathrm{~K}$ and $<$ IOK peptides, respectively.

\section{RESULTS}

Detection of toxin antigen in inner and outer membrane protein preparations

Although biologically active membrane-bound toxin is released from aerobically grown $V$. cholerae by sodium deoxycholate treatment (Fernandes \& Smith, 1977), it is not known whether the toxin is tightly bound to the outer and/or the inner membrane. When tested in double diffusion agarose gels, the outer membrane protein $\left(1 \mathrm{mg} \mathrm{ml}^{-1}\right)$ preparations of aerobically grown cells gave a precipitin band within $48 \mathrm{~h}$ with anticholeragenoid ( $\mathrm{I}$ : $\mathrm{IO}$ dilution in PBS) and with antitoxin ( $\mathrm{I}$ : 10 dilution in PBS). These precipitin bands showed a reaction of identity with the precipitin band formed between the antitoxin or anticholeragenoid and purified cholera toxin $\left(0.3 \mathrm{mg} \mathrm{ml}^{-1}\right)$. Similar results were obtained with inner membrane protein $\left(2 \mathrm{mg} \mathrm{ml}^{-1}\right)$ preparations of aerobically grown cells, but the precipitin lines were faint and appeared after 3 days. This could be the result of a low concentration of toxin in the inner membrane. The outer inner and membrane proteins of anaerobically grown cells did not give a detectable precipitin band with either antitoxin or anticholeragenoid.

\section{Characterization of outer and inner membrane proteins}

The inner and outer membrane proteins were examined for peptides of similar molecular weights to the toxin peptides. Under anaerobic conditions, the quantity of the major polypeptide of mol. wt 42000 in the outer membrane was approximately half of that found under aerobic conditions. In addition, both inner and outer membranes from aerobically grown cells contained polypeptides with mol. wts of approximately 22000 and $<10000$ which were not found in anaerobically grown organisms (Fig. I $b, c, d, e$ ). The amount of 


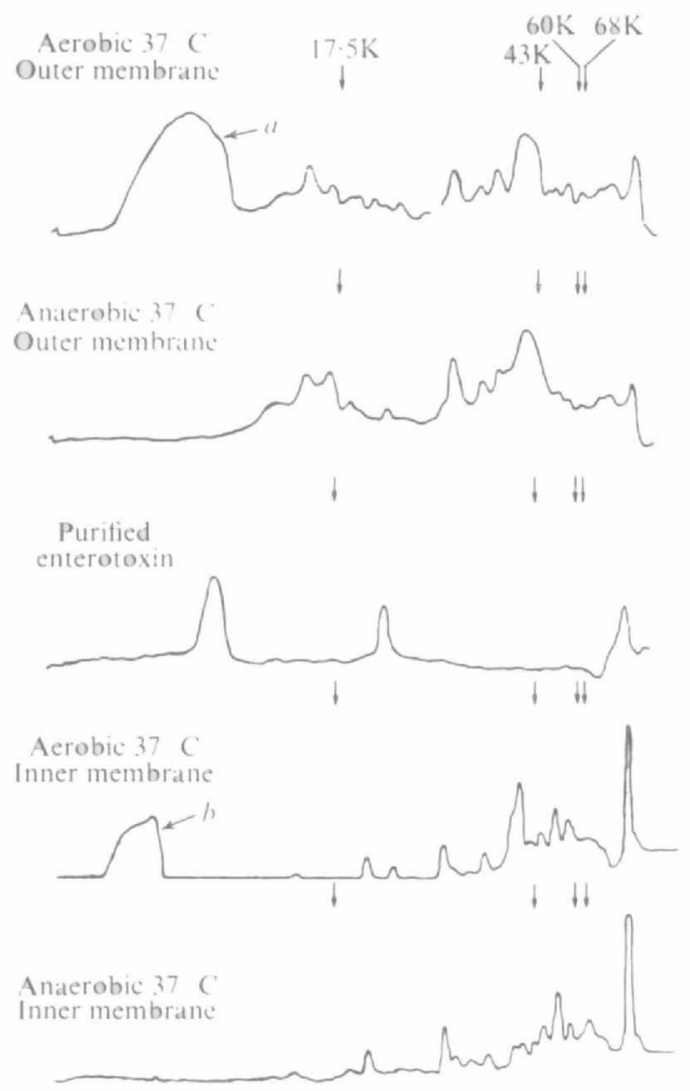

Fig. 2

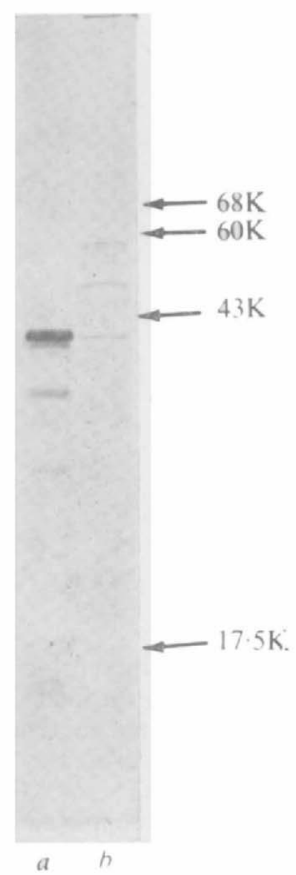

Fig. 3

Fig. 2. Densitometric scans of stained i $8 \%$ polyacrylamide gel of $V$. cholerae $569 \mathrm{~B}$ outer and inner membrane proteins and purified cholera toxin. Molecular weight standards (see Fig. 1 legend) are indicated by arrows. Arrow $a$ indicates the 4 to IOK peptide in the outer membrane of aerobically grown organisms which is absent from the outer membrane of anaerobically grown organisms. Arrow $b$ indicates the $4 \mathrm{~K}$ peptide in the inner membrane of aerobically grown organisms which is absent from the inner membrane of anaerobically grown $V$. cholerae. The molecular weights of the control toxin components are $2 \mathrm{IK}$ ( $\mathrm{A}_{1}$ subunit) and I IK (B subunit).

Fig. 3. Envelope proteins of $V$. cholerae 569B grown aerobically at $37^{\circ} \mathrm{C}$, extracted with $0.1 \%$ sodium deoxycholate and separated by SDS-polyacrylamide (10\%) gel electrophoresis. (a) Outer membrane proteins, $(b)$ inner membrane proteins. Molecular weight standards are the same as shown in Fig. $I$.

the 22000 mol. wt peptide in the inner membrane was 2.8 times lower than that found in the outer membrane. The amounts of the $<$ I0000 mol. wt peptides could not be determined on the $10 \%$ gels.

\section{Comparison of membrane proteins with purified cholera toxin}

Gel electrophoresis of cholera toxin showed three bands with approximate mol. wts of $2 \mathrm{I} 000$ ( $\mathrm{A}_{1}$ polypeptide), I I 000 (subunit of $\mathrm{B}$ fragment) and 5000 ( $\mathrm{A}_{2}$ polypeptide) (Fig. I $a$ ). Therefore, the outer and inner membranes of aerobically grown $V$. cholerae contained at least two peptides with molecular weights similar to those of the toxin subunits $A_{1}$ and $A_{2}$. Under anaerobic conditions, these peptides could not be detected in either inner or outer membranes. This observation correlates with the absence of biologically active membranebound toxin in anaerobically grown organisms (Fernandes \& Smith, 1977). 


\section{Separation of low molecular weight peptides}

Since low molecular weight peptides migrated with the bromophenol blue tracking dye in $10 \%$ polyacrylamide gels, samples were lanalysed on $18 \%$ polyacrylamide gels to separate these peptides. A peptide with a mol. wt of 4000 to 10000 was found in the outer membrane of aerobically grown organisms but not in that of anaerobically grown organisms (Fig. 2). When lower concentrations of the sample were used, the peptide appeared to have a mol. wt of about 6000 . When inner membrane proteins were analysed on $18 \%$ gels, a peptide with a mol. wt of about 4000 was found only in the samples from aerobically grown organisms (Fig. 2). This peptide might be similar to the peptide $(6000 \mathrm{~mol}$. wt) found in the outer membrane of the same cells, since the latter had a mol. wt between 4000 and 6000 on overloaded gels. If $<10000 \mathrm{~mol}$. wt peaks in the outer and inner membranes of aerobically grown organisms were from the same peptide, then the content of this peptide in the inner membrane was only about a quarter of that in the outer membrane.

\section{Sodium deoxycholate extraction}

When $V$. cholerae was grown both aerobically and anaerobically at $37^{\circ} \mathrm{C}$ and extracted with sodium deoxycholate $(0 \cdot \mathrm{I} \% \mathrm{w} / \mathrm{v})$, several peptides were released, probably due to the detergent action of sodium deoxycholate. However, peptides with mol. wts of 22000 and 6000 were released only from aerobically grown bacteria (Fig. 3).

\section{Trypsin digestion of envelopes}

Trypsin releases membrane-bound penicillinase which is an intermediary form of extracellular penicillinase (Lampen, 1974). Trypsin released several membrane proteins ranging in mol. wt from 45000 to 8000 from envelopes of both aerobically and anaerobically grown $V$. cholerae; peptides with mol. wts of about 22000 and 6000 were released only from envelopes of aerobically grown organisms.

\section{DISCUSSION}

Large amounts of toxin remain membrane-bound when $V$. cholerae is grown aerobically at $37^{\circ} \mathrm{C}$, but under anaerobic conditions the toxin is not held in the membrane-bound state, since it is released into the growth medium (Fernandes \& Smith, 1977). In this report, the toxin antigen was detected in the inner and the outer membranes of organisms grown aerobically using both anticholeragenoid and antitoxin. No toxin antigen was detected in the membranes from anaerobically grown organisms. We have also demonstrated that at least two peptides, with mol. wts of 22000 and 6000 , are present in the envelope of aerobically grown cells but not in that of anaerobically grown cells. Since the $A_{1}$ and $A_{2}$ subunits of cholera toxin have mol. wts of 21000 and 5000, we postulate that the 22000 and the 6000 mol. wt peptides may be the $A_{1}$ and $A_{2}$ subunits or their precursors. As these peptides have not yet been shown to react with antitoxin or to possess toxic activity, further characterization is necessary before these peptides can be positively identified as the toxin subunits.

Although the B subunit was detected in the outer and inner membrane of aerobically grown cells by Ouchterlony double diffusion analysis using anticholeragenoid serum (anti-B subunit), we were unable to identify by gel electrophoresis the peptide which corresponded to the B subunit in the membrane. We do not know whether the difference in mol. wt between the $6000 \mathrm{~mol}$. wt peptide in the outer membrane and the $4000 \mathrm{~mol}$. wt peptide in the inner membrane was the result of 'trailing' by the former due to the large amount of this peptide in the outer membrane preparations. It could also be caused by the peak being made up of two or more peptides of which at least one had a slightly higher 
mol. wt. On the other hand, the outer membrane peptide might be larger than the inner membrane peptide since the latter might be glycosylated or modified in some other way as it passes from the inner to the outer membrane. It should also be noted that if the $6000 \mathrm{~mol}$. wt peptide is the $A_{2}$ subunit, its quantity in the outer membrane cannot be compared with the relatively small amount of the $A_{2}$ subunit in the toxin molecule.

The 22000 and 6000 mol. wt peptides were tightly bound to the envelope because they were not released during Triton X-100 extraction. Therefore, these peptides were not contaminants of the membrane by toxin in the growth medium. Surprisingly, anaerobically grown bacteria contain no membrane-bound toxin in spite of the fact that they secrete large amounts of toxin (Fernandes \& Smith, 1977). One explanation is that the toxin that is transported across the envelope of anaerobically grown cells cannot remain tightly bound to the inner or the outer membranes since the envelopes of anaerobically grown cells seem to be structurally altered (Fernandes et al., 1977).

Sodium deoxycholate releases membrane-bound toxin from aerobically grown cells (Fernandes \& Smith, 1977). In this study, we have shown that several peptides, including the 22000 and $6000 \mathrm{~mol}$. wt peptides, are released by sodium deoxycholate. Presumably, the sodium deoxycholate present in bile could release these membrane-bound peptides in vivo. In addition to bile salts, the intestinal milieu contains proteolytic enzymes which may facilitate the release of these membrane-bound peptides. To test this hypothesis, we added trypsin to isolated envelopes from aerobically grown cells and showed that the 22000 and 6000 mol. wt peptides were also released by trypsin. Thus, these peptides could conceivably be released in vivo by proteases which are secreted by $V$. cholerae. Our results are consistent with the finding of Schneider \& Parker (1975) that protease-negative strains of $V$. cholerae are less virulent than protease-positive strains. We suggest therefore that protease-negative strains spontaneously release less membrane-bound toxin than proteasepositive ones, assuming that toxin synthesis is equivalent in both strains.

The results of this study might also explain the production of choleragenoid, a natural toxoid secreted by $V$. cholerae, which consists of only the B subunit. Finkelstein, Peterson \& LoSpalluto (197I) have shown that it is formed as a result of breakdown of the active toxin in the culture medium. On the other hand, Callahan \& Richardson (1973) have shown that choleragenoid can be found in the growth medium under conditions in which the active toxin is not produced. As the subunits can be transported separately across the membrane, we propose that under certain growth conditions the B polypeptide only could be released.

In this report we have shown that peptides which may be precursors of the toxin polypeptides are found tightly bound to the envelope of $V$. cholerae under optimal growth conditions. Further characterization of these polypeptides should be useful in explaining the molecular mechanism of transport of macromolecules, such as enterotoxin, across the inner and outer membranes of Gram-negative bacteria. Since other Gram-negative bacteria such as Escherichia coli (Finkelstein, 1975) also secrete an enterotoxin, we believe that these studies will be useful in studying the physiology of toxin secretion in Gram-negative bacteria.

We wish to thank Drs T. F. Anderson, J. T. Ou, J. McMichael, S. Franklin and J. M. Clark for their helpful criticism of this manuscript, and Mrs Barbara Hulme for her excellent secretarial work.

This work was supported by United States Public Health Service Grants from the National Institutes of Health: Postdoctoral Training Grant CA-09035, Grant AI-IO4I 4 to M.E.B., Grants CA-06927 and RR-05539 to The Institute for Cancer Research, and an Appropriation from the Commonwealth of Pennsylvania. 


\section{REFERENCES}

AMEs, G. F. (1974). Resolution of bacterial proteins by polyacrylamide gel electrophoresis. Journal of Biological Chemistry 249, 634-644.

Callahan, L. T. \& Richardson, S. H. (1973). Biochemistry of Vibrio cholerae virulence. III. Nutritional requirements for toxin production and the effect of $\mathrm{pH}$ on toxin elaboration in chemically defined media. Infection and Immunity $\mathbf{7}$, 567-572.

Fernandes, P. B. \& Smith, H. L. (1977). The effect of anaerobiosis and bile salts on the growth and toxin production by Vibrio cholerae. Journal of General Microbiology 98, 77-86.

Fernandes, P. B., Clark, J. M. \& Smith, H. L. (1977). Morphology of Vibrio cholerae during enterotoxin production under anaerobic conditions. Journal of Ultrastructure Research $\mathbf{5}^{\mathbf{8}}$, 252-260.

FinKelstein, R. A. (1975). Cholera enterotoxin. In Microbiology - 1975, pp. 236-24I. Edited by D. Schlessinger. Washington: American Society for Microbiology.

Finkelstein, R. A., Peterson, J. W. \& LoSpalluto, J. J. (I97I). Conversion of cholera exo-enterotoxin (choleragen) to natural toxoid (choleragenoid). Journal of Immunology 106, 868-871.

Holmgren, J., LöNNROTH, I. \& SVENNERHOLM, L. (1973). Tissue receptor for cholera exotoxin: postulated structure from studies with $\mathbf{G M}_{1}$ ganglioside and related glycolipids. Infection and Immunity 8, 208-214.

INOUYE, M. \& YEE, M. (1972). Specific removal of proteins from the envelope of Escherichia coli by protease treatments. Journal of Bacteriology 112. 585-592.
LAEMMLI, U. K. \& FAVRE, M. (1973). Maturation of the head of bacteriophage T4. I. DNA packaging events. Journal of Molecular Biology 80, 575-599.

LAMPEN, J. O. (1974). Movement of extracellular enzymes across cell membranes. Symposia of the Society for Experimental Biology 28, 35I-374.

Lowry, O. H., Rosebrough, N. J., FARR, A. L. \& RANDALL, R. J. (I95I). Protein measurement with the Folin phenol reagent. Journal of Biological Chemistry 193, 265-275.

Lugtenberg, B., Peters, R., Bernheimer, H. \& BERENDSEN, W. (1976). Influence of cultural conditions and mutations on the composition of the outer membrane proteins of Escherichia coli. Molecular and General Genetics 147, 25I-262.

Osborn, M. J., Gander, J. E., PARISI, E. \& Carson, J. (1972). Mechanism of assembly of the outer membrane of Salmonella typhimurium. Journal of Biological Chemistry 247, 3962-3972.

RosenbusCH, J. P. (I974). Characterization of the major envelope protein from Escherichia coli: regular arrangement on the peptidoglycan and unusual sodium dodecyl sulfate binding. Journal of Biological Chemistry 249, 8019-8029.

Schnartman, C. (1971). Effect of ethylenediaminetetraacetic acid, Triton X-IOO, and lysozyme on the morphology and clinical composition of the cell wall of Escherichia coli. Journal of Bacteriology I08, 553-563.

SCHNEIDER, D. \& PARKeR, C. (1975). Protease mutants of Vibrio cholerae. In Proceedings of the Eleventh Joint Conference on Cholera, pp. 127I33. 